\title{
Sınıf Öğretmenlerinin Fen Bilimleri Dersinde Kullandıkları Öğretim Yöntem, Teknik ve Değerlendirme Araçlarına İlişkin Görüşleri
}

\author{
Zeki APAYDIN1, Mehmet Ali KANDEMİR2 \\ ${ }^{1}$ Doç. Dr., Ondokuz.Mayıs Üniversitesi, zapaydin@omu.edu.tr \\ 2 Ögretmen, MEB, mehmetalikandemir10@gmail.com
}

DOI: http://dx.doi.org/10.14582/DUZGEF.1884

\begin{abstract}
ÖZ
Bu çalışmada, sınıf öğretmenlerinin fen bilimleri dersinde kullandıkları öğretim yöntem, teknik ve değerlendirme araçlarına ilișkin görüșlerini ortaya çıkarmak amaçlanmıștır. Bu çalıșma Balıkesir'in Bandırma ilçesinde 6 farklı okulda 70 sınıf öğretmeni ile gerçekleştirilmiştir. Bu çalışma nitel araştırma desenlerinden biri olan durum çalışmasına göre düzenlenmiştir. Veriler araştırmacılar tarafindan geliştirilen yarı yapılandırılmış görüşme formundan elde edilmiştir. Formdan elde edilen veriler betimsel analiz yöntemi ile analiz edilmiştir. Bu araştırmada sınıf öğretmenlerinin fen bilimleri derslerinde düz anlatım yönteminin yanında, yapılandırmacı öğrenme teorisinin önerdiği öğrenciyi merkeze alan yöntem ve teknikleri de kullandığı sonucuna varılmıştır. Bununla birlikte derslerde geleneksel ölçme ve değerlendirme araçlarının, alternatif ölçme ve değerlendirme araçlarınden daha fazla kullanıldığı sonucuna varılmıştır.
\end{abstract}

Anahtar Kelimeler: Alternatif ölçme ve değerlendirme araçları, geleneksel ölçme ve değerlendirme araçları, öğretim yöntem ve teknikleri

\section{Primary Teacher Opinions about Teaching Methods and Techniques and Evaluation Tools and Techniques Used in Science Course}

\begin{abstract}
The purpose of this study is to determine primary teacher opinions about teaching methods and techniques and evaluation tools and techniques used in science course. This study was conducted located in Bandirma county of Ballkesir province with the participation of total 70 primary school teachers in 6 different schools in during 2017-2018 academic year. This study is designed as a qualitative research and planned according to case study design. The data were acquired by means of semi-structured interview form developed by the researchers. The data analyses were subject the descriptive analysis. The result, of the study, showed that primary school teachers preferred expository instruction methods and techniques most but that they did not find it sufficient alone and supported it with another constructivist approach methods and techniques in science course. This however, it was found that the traditional measurement tools were preferred more than alternative tools.
\end{abstract}

Keywords: Alternative measurement tools, teaching methods and techniques, traditional measurement tools,

\section{GİRİ̧̧}

Eğitim ve öğretim sürecinde yöntem ve teknik şeçimi çok önemlidir. Çünkü öğretilecek konunun kazanımlarını öğrenciler çeşitli yöntem ve teknikler sayesinde öğrenirler (Aykaç, 2005; Demir \& Özden, 2013). Yöntem, eğitim ve öğretim sürecinde izlenen yolu belirtirken; teknik ise, yöntemin uygulama biçimi olarak tanımlanabilir (Saygılı, 2015). Yöntemler, kazanımları edindirmede, öğrencilerin gelişimlerini takip etmede büyük öneme sahiptir. Bundan dolayı öğretim etkinlikleri yöntemlere dayalı olarak yürütülmektedir. Yöntem kullanmadan rastgele yapılan eğitim süreçlerinde başarı düşmektedir. İyi seçilen ve uygulanan yöntemler öğrenmeyi kolaylaştırmakta, öğrencilerin dil, zihin, ve sosyal gelişimine doğrudan katkıda bulunmakta eğitimin verimi arttırmaktadır. Teknikler ise, yöntemin amaç ve alt amaçlara ulaşmasını sağlayan araçlardır. Aynı zamanda materyal destekçisi, eğitim ve öğretim sürecinin kalitesini arttırmak isteyen öğretmenin başvurduğu sanatlar ve becerilerdir ( Güneş, 2014). Alan yazında derslerde kullanılan yöntem ve tekniklerle ilgili çalışmalar incelendiğinde, öğretmenlerin yapılandırmacı öğrenme teorisine uygun öğretim yöntem ve teknikleri hakkında 
yeterli donanıma sahip olmadıkları görülmektedir (Akçay, Akçay \& Kurt, 2016). Bununla beraber Türk eğitim sisteminde hala ezberci anlayışın devam ettiği görülmektedir (Kardaş \& Uca, 2016). Öğretmenler derslerde en fazla düz anlatım ve soru cevap yöntemlerini kullanmaktadırlar (Aydemir, 2012; Sakallı, Hürsen \& Özçınar, 2007; Taşkaya \& Sürmeli, 2014). Oysaki öğretmenin en temel görevi, öğretim programının kazanımlarını dikkate alarak ve meslek bilgisini kullanarak öğrencinin bilişinde anlamlı ve kalıcı bir öğrenmenin gerçekleşmesine rehberlik etmektir. Alan bilgisi ve meslek bilgisi olmayan öğretmenlerin çıkardıkları ürünler, istenilen kalitede olamamaktadır (Erden, 1993). Öğretmenlerin istenilen kalitede ürün ortaya koyabilmeleri için, öğrencilerin üst düzey düşünme becerilerini geliştirme firsatı sunan, öğrenciler arasında işbirliğine firsat veren, öğrencilere etkileşerek öğrenme olanağ1 veren yöntem ve tekniklerin etkin olarak kullanılması gerekmektedir (Aykaç, 2011; Taşkaya \& Sürmeli, 2014). Öğretmenlerin çağın gereksinimlerine cevap verecek eğitim ve öğretim faaliyetleri düzenlemeleri, çağın gereklerine uygun bireylerin yetişmesine katkı sağlayacaktır (Kardaş \& Öztürk, 2015). Öğretmenler ders planlaması yaparken sınıfta bulunan öğrencilerin ilgileri, öğrencilerin hazır bulunuşluk düzeyleri, öğrenme stilleri, öğretilecek konunun kazanımları, öğrenci sayısı, eğitim ortamı, maliyet, zaman, konuların niteliği ve süresini dikkate alarak yöntem ve teknik belirlemelidirler (Açıgöz, 2014; Akçay, Akçay \& Kurt, 2016; Efe \& Aslan-Efe, 2018; Gözütok, 2007; Lubbers \& Gorcyca, 1997; Savage \& Armstrong, 1996; Türkben, 2015). Yetkin öğretmenler bu özellikleri dikkate alarak yöntem ve teknik belirleyip, yöntem ve tekniklerin yararlı yönlerinin yanında, sınırlı olduğu yerleri de göz önünde bulundururlar (Gözütok, 2007).

Öğrencilerin öğrenme stilleri farklı olduğu için farklı yöntem ve tekniklerle öğrenirler (Hemlick \& Norland, 1994). Öğretmen iyi bir öğretim için öğrencilerini çok iyi tanımalı ve onların özelliklerine göre farklı yöntem ve teknikler kullanmalıdır (Slavin, 1991). Özellikle yapılandırmacı öğrenme teorisinin temel alındığ 2005 yılı ve sonrası fen bilimleri programlarında, öğretmenlerin; öğrencilerin farklı düzey ve öğrenme alanlarının kapsamındaki konuları etkili ve kalıcı şekilde öğrenmelerini sağlayacak yöntem ve teknikleri kullanabilme becerisinde olmaları vurgulanmıştır. Derslerde özellikle fen bilimleri dersinde, kullanılan yöntem ve teknikler öğrencilerin fen bilimleri derslerine yönelik tutumları, akademik başarıları ve gerçekleştirilen kazanımların kalıcılığı üzerinde etkilidir (Akşid \& Şahin, 2011; Aydede, 2009; Çakır, Şenler \& Taşkın, 2007; Hançer, Şensoy \& Yıldırım, 2003).

Eğitim ve öğretim sürecinde öğrencilerin aktif olmasını sağlayacak yöntem ve tekniklerin kullanılması, gerçekleştirilen kazanımların kalıcılık süresinin artmasına katkıda bulunur (Slavin, 2013). Fen bilimleri derslerinde kullanılabilecek ve öğrenciyi aktif kılabilecek bazı yöntem ve teknikler aşağıda verilmiştir. Bunlar:

Tartışma yöntemi, argümantasyon yöntemi, grup tartısması, sınıf tartışması, örnek olay yöntemi, beyin firtınası, rol oynama, drama, 5E modeli, probleme dayalı öğrenme, proje, altı şapkalı düşünme tekniği, jigsaw tekniği, v diyagramı, beyin firtınası, istasyon tekniğidir (Çepni, 2016; Saygılı, 2015). Eğitim ve öğretim sürecinde çeşitli faktörlere göre yöntem ve teknik belirlenip uygulanıldıktan sonra; hem öğrencilerin başarısı, hemde eğitim ve öğretim sürecinin etkililiği değerlendirilir (Baykul \& Turgut, 2010). Yeni fen bilimleri öğretim programında ölçme ve değerlendirmede, öğretmen ve ögrencinin aktif olacağı alternatif ölçme değerlendirme araçlarının kullanımı ön plana çıkarılmaktadır. Bu ölçme ve değerlendirmenin geleneksel ölçme ve değerlendirme araçlarından çok, eğitim sürecinin ve sonucun birlikte ele alınıp değerlendirildiği performans değerlendirme, kendini değerlendirme, akran değerlendirme, yapılandırılmış grid, kavram haritaları, kelime ilişkilendirme testleri, tanılayıcı dallanmış ağaç, rubrik, poster, portfolyo, proje gibi alternatif ölçme ve değerlendirme araçları kullanılarak yapılması vurgulanmaktadır. Bu ölçme ve değerlendirme araçlarının kullanılmasındaki amaç öğrencinin neyi bilmediğini değil, bildiklerini ortaya çıkarmaktır (Dokumac1-Sütçü \& Bulut, 2016; Karadüz, 2009; Karamustafaoğlu, Çağlak \& Meşeci, 2012; Kilmen \& Kösterelioğlu, 2017; MEB, 2013; Özenç, 2013; Şahin, Öztürk \& Teker, 2015; Yazıcı \& Sözbilir, 2014).

Öğretmenlerin fen bilimleri dersinde kullandıkları öğretim yöntem ve teknikleri ile bu öğretim sürecinin başında, öğretim sürecinde ve süreç sonunda kullandığı ölçme ve değerlendirme araçları merak konusudur. Bu konuyla ilgili araştırma ve gözlem sonuçlarına gereksinim vardır. Bu gereksinimin giderilmesine katkıda bulunmak amacıyla bu araştırmanın yapılmasına ihtiyaç duyulmuştur (Akçay, Akçay \& Kurt, 2016). 


\subsection{Araştırmanın Amacı}

Bu çalışmanın amacı sınıf öğretmenlerinin 4. sınıf fen bilimleri dersinde kullandıkları öğretim yöntem, teknik ve değerlendirme araçlarına ilişkin görüşlerini belirlemektir. Bu amaca ulaşma yönelik araştırma soruları aşağıda verilmiştir. Bunlar:

1. Sınıf öğretmenlerinin fen bilimleri dersinde kullandıkları yöntem ve teknikler nelerdir?

2. Sınıf öğretmenlerinin fen bilimleri dersinde kullandıkları ölçme ve değerlendirme araçları nelerdir?

\section{YÖNTEM}

\subsection{Araştırmanın Modeli}

Bu çalışma, nitel araştırma modellerinden durum çalışmasına göre tasarlanmıştır.

\section{2. Çalışma Grubu}

Bu çalışma, 2017-2018 eğitim ve öğretim ylında Balıkesir’in Bandırma ilçesinde 6 farklı okulda görev yapan 70 sınıf öğretmeninin katılımı ile yapılmıştır. Çalışma grubun belirlenmesinde basit seçkisiz örnekleme yöntemi kullanılmışır (Büyüköztürk, Çakmak, Akgün, Karadeniz \& Demirel, 2016).

\subsection{Verilerin Toplanmas1}

$\mathrm{Bu}$ çalışmada veriler araştırmacılar tarafindan geliştirilmiş olan yarı yapılandırılmış görüşme formundan elde edilmiştir. $\mathrm{Bu}$ form ile sınıf öğretmenlerinin fen bilimleri dersinde kullandığı yöntem, teknik ve değerlendirme araçlarına yönelik görüşleri alınmıştır. Veri toplama aracındaki maddeler hazırlandıktan sonra, kapsam geçerliliğini sağlamak amacıyla uzman görüşü alınmış, gerekli düzeltmeler yapılmıştır. Görüşme formu hazırlandıktan sonra çalışmaya katılmayacak olan 5 öğretmene bu form okutulmuş, anlayamadıkları yerler olup olmadığı sorulmuştur. Sorular mantıklı bir sıra ile açık, anlaşılır bir şekilde formu cevaplayan kişiyi yönlendirici ifadelerden kaçınılarak hazırlanmıştır. Örneklem sayısının fazla olmasından dolayı görüşme formu yanıtlayıcılar tarafindan doldurulmuştur. Yanıtlayıcıların formu doldurması esnasında süre sınırsız bırakılmış ve elde edilen veriler arasındaki tutarlık sürekli kontrol edilerek iç geçerlilik sağlanmaya çalışılmıştır. Çalışmanın tüm aşamaları ayrıntılı olarak verilerek dış geçerlilik sağlanmaya çalışılmıştır (Yöntemi, veri toplama aracı, çalışma grubu vb.). Kura usulü seçilen iki yanıtlayıcıya ait verilerin kod ve kategoriler karşılaştırılmış (yanıtlayıcıların kesişimlerinin sayıs1/ tek formdaki madde sayısı) formdan elde edilen iç tutarlılık (güvenirlik) yüzdesi \%88 olarak bulunmuştur. Bunun yanında iç tutarlılığ arttırmak için bulgular yorum yapılmadan verilmiştir. Elde edilen verilerin analizinde kullanılan kavramsal çerçeve, veri toplama ve veri analiz yöntemleri ayrıntılı olarak verilerek dış güvenirlik sağlanmaya çalışılmıştır (Yıldırım \& Şimşek, 2008; Çepni, 2010).

\subsection{Verilerin Analizi}

Görüşme formundan elde edilen verilerin analizinde betimsel analiz yönteminden yararlanılmıştır. Betimsel analizde veriler görüşülen kişiden elde edildiği şekilde aktarılır. Elde edilen veriler daha önceden belirlenmiş temalara göre sınıflandırılır (Altunışık, Çoşkun, Yıldırım \& Bayraktaroğlu, 2010; Yıldırım \& Şimşek, 2008).

\section{BULGULAR}

Yarı yapılandırılmış görüşme formundan elde edilen verilerin içerik analizi yöntemine göre analiz edilmesiyle oluşan kod ve kategoriler aşağıdaki tablo1'de verilmiştir.

Araştırmanın sorularından birincisi, "Sınıf öğretmenlerinin fen bilimleri dersinde kullandıkları yöntem ve teknikler nelerdir?" sorusudur.

Tablo 1. Öğretmenler tarafindan kullanılan yöntem, tekniklere ait kategori, kod ve frekanslar

\begin{tabular}{clc}
\hline \multicolumn{1}{c}{ Kategoriler } & \multicolumn{1}{c}{ Kodlar } & Frekans \\
\hline Yöntem ve teknikler & Anlatım yöntemi & 66 \\
& Gösterip yaptırma & 66 \\
& Örnek olay yöntemi & 64 \\
& Problem çözme & 64 \\
& Deney yöntemi & 62 \\
& Beyin firtınası & 60 \\
& Kavram haritası & 55 \\
& Soru cevap & 54 \\
\hline
\end{tabular}




\begin{tabular}{ll}
\hline Drama & 52 \\
Gösteri & 48 \\
Tahmin gözlem açıllama & 46 \\
Rol oynama & 42 \\
Zihin haritası & 41 \\
Balık kılçı̆̆1 & 39 \\
Gezi gözlem & 37 \\
Altı şapkalı düşünme & 32 \\
İstasyon & 29 \\
Karşllkklı sorgulama & 29 \\
Düşün eşleş paylaş & 25 \\
Münazara & 25 \\
Kartopu & 24 \\
Argümantasyon & 20 \\
V diyagramı & 20 \\
Sandviç & 18 \\
Jigsaw II & 16 \\
Jigsaw I (Ayrilıp Birleşme I) & 16 \\
Zit panel & 14 \\
\hline
\end{tabular}

Tablo 1 incelendiğinde bu çalışmada görüş bildiren öğretmenlerin, fen bilimleri dersinde kullandıkları yöntem ve teknikler ile bu yöntemve teknikleri kullanan öğretmen sayıları şöyledir: Anlatım yöntemi 66, gösterip yaptırma 66, örnek olay yöntemi 64, problem çözme 64, deney yöntemi 62, beyin firtınası 60, kavram haritası 55, soru cevap 54, drama 52, gösteri 48, tahmin gözlem açıllama 46, rol oynama 42, zihin haritası 41, balık k1lçığı 39, gezi gözlem 37, altı şapkalı düşünme 32, istasyon 29, karşlıklı sorgulama 29, düşün eşleş paylaş 25 , münazara 25, kartopu 24, argümantasyon 20, v diyagramı 20, sandviç 18, jigsaw II 16, jigsaw I 16, zıt panel 14 katılımcı sınıf öğretmeni tarafından fen bilimleri derslerinde kullanılmaktadır. Sınıf öğretmenlerinin bu yöntemleri kullanma nedenleri tablo 2'de verilmiştir.

Tablo 2. Yöntem ve tekniklerin kullanılma nedenleri

\begin{tabular}{|c|c|}
\hline Kullanılma Nedeni & Frekans \\
\hline 1. Konu ve kazanımlara uygun olması & 61 \\
\hline 2. Öğrenmenin kalıcılık süresini uzatmas1 & 60 \\
\hline 3. Öğrenci merkezli olması & 55 \\
\hline 4. Kavram yanılgılarını gidermek için & 60 \\
\hline $\begin{array}{l}\text { 5. Öğrencilerin hazır bulunuşluk seviyesinin } \\
\text { uyounluŏu }\end{array}$ & 55 \\
\hline $\begin{array}{l}\text { uygunluğu } \\
\text { 6. Akademik basarıvı arttırmas1 }\end{array}$ & $\begin{array}{l}55 \\
56\end{array}$ \\
\hline 7. Dersi zevkli ve eğlenceli hale getirmesi & 50 \\
\hline 8. Üst düzey düşünme becerilerinin gelişimine katkıda & \\
\hline $\begin{array}{l}\text { bulunması (Eleştirel-analitik- yaratıcı düşünme) } \\
\text { 9. Birden çok duyu organının kullanımına imkân }\end{array}$ & 38 \\
\hline $\begin{array}{l}\text { tanıması } \\
\text { 10. Öğrencilerin etkin katılımını sağlaması }\end{array}$ & $\begin{array}{l}39 \\
43\end{array}$ \\
\hline 11. Derse yönelik olumlu tutum geliştirmesi & 40 \\
\hline 12. Öğrencilerin ilgisini çekmesi & 41 \\
\hline 13. Öğrencileri araştırmaya yönlendirmesi & 42 \\
\hline 14. Öğrencilerin dikkatini toplaması & 34 \\
\hline 15. Anlamlı öğrenmeyi sağlaması & 44 \\
\hline 16. Konuların zamaninda yetişmesini sağlaması & 26 \\
\hline 17. Farklı zekâ alanlarına hizmet etmesi & 40 \\
\hline 18. Farklı ögrenme stillerine hizmet etmesi & 36 \\
\hline 19. Öğrencilerin güdülenmesini kolaylaştırması & 33 \\
\hline 20. Kolay ve az zaman almasi & 22 \\
\hline
\end{tabular}

Tablo 2 incelendiğinde bu çalışmada görüş bildiren öğretmenlerin yöntem ve tekniği kullanma sebepleri ve frekansları şöyledir: Konu ve kazanımlara uygun olması 61, öğrenmenin kalıcllı süresini uzatması 60, öğrenci merkezli olması 55, kavram yanılgılarını gidermek için 60, öğrencilerin hazır bulunuşluk seviyesinin uygunluğu 55, akademik başarıyı arttırması 56, dersi zevkli ve eğlenceli hale getirmesi 50, üst düzey düşünme becerilerinin gelişimine katkıda bulunması 38, birden çok duyu organının kullanımına imkân tanıması 39, öğrencilerin etkin katılımını sağlaması 43, derse yönelik olumlu tutum geliştirmesi 40, öğrencilerin ilgisini çekmesi 41, öğrencileri araştırmaya yönlendirmesi 42, öğrencilerin dikkatini toplaması 34, anlamlı öğrenmeyi sağlaması 44, konuların zamanında yetişmesini sağlaması $\quad 26$, farklı zekâ alanlarına hizmet etmesi $\quad 40, \quad$ farklı öğrenme stillerine hizmet etmesi 36, öğrencilerin güdülenmesini kolaylaştırmas1 33, kolay ve az zaman almas1 22 katılımcı sınıf öğretmeni tarafından kullanılma nedeni olarak belirtilmektedir. 
Araştırma sorularından ikincisi, "sınıf öğretmenlerinin fen bilimleri dersinde kullandıkları ölçme ve değerlendirme araçları nelerdir?" sorusudur.

Tablo 3. Kullanılan ölçme ve değerlendirme araç ve teknikleri ait kategori, kod ve frekanslar

\begin{tabular}{llc}
\multicolumn{1}{c}{ Kategoriler } & \multicolumn{1}{c}{ Kodlar } & Frekans \\
\hline Ölçme ve değerlendirme araç ve & Çoktan seçmeli testler & 66 \\
teknikleri & Yazılı yoklamalar & 56 \\
& Sözlü yoklamalar & 56 \\
& Boşluk doldurmalı testler & 56 \\
& Doğru yanlış testler & 56 \\
& Eşleştirmeli testler & 50 \\
& Performans değerlendirme & 50 \\
& Kavram haritaları & 50 \\
& Portfolyo değerlendirme & 47 \\
& Poster & 44 \\
& Öz değerlendirme & 40 \\
& Derecelendirme ölçeği & 40 \\
& Rubrik & 38 \\
& Proje & 38 \\
& Akran değerlendirme & 36 \\
& Kontrol listesi & 34 \\
& Yapıllandırılmış grid & 28 \\
Tanılayıcı dallanmış ağaç & 28 \\
\hline
\end{tabular}

Tablo 3 incelendiğinde; bu çalışmada görüş bildiren katılımcı öğretmenlerin fen bilimleri dersinde kullandıkları ölçme ve değerlendirme araçları ve bu ölçme değerlendirme araçlarını kullanan öğretmen sayıları şöyledir:

Çoktan seçmeli testler 66, yazılı yoklamalar 56, sözlü yoklamalar 56, boşluk doldurmalı testler 56, doğru yanlış testler 56, eşleştirmeli testler 50, performans değerlendirme 50, kavram haritaları 50, portfolyo değerlendirme 47, poster 44, öz değerlendirme 40, derecelendirme ölçeği 40, rubrik 38, proje 38, akran değerlendirme 36, kontrol listesi 34, yapılandırılmış grid 28, tanılayıcı dallanmış ağaç 28 katılımcı sınıf öğretmeni tarafından kullanılmaktadır. Sınıf öğretmenlerinin bu ölçme ve değerlendirme araçlarını kullanma nedenleri tablo 4’te verilmiștir.

Tablo 4. Ölçme ve değerlendirme araçlarının kullanılma nedenleri

\begin{tabular}{lll}
\hline \multicolumn{1}{c}{ Kullanılma Nedeni } & Frekans \\
\hline 1. Öğrencilerin akademik başarısını belirlemesi & 57 \\
2. Kullanılan yöntem ve tekniklerin etkililiğini belirlemesi & 52 \\
3. Konu bitiminde öğrenme eksiklerinin belirlenebilmesi & 53 \\
4. Sınıfın seviyesini belirlemesi & 56 \\
5. Öğrencinin hazır bulunuşluk seviyesini belirleyebilmesi & 48 \\
6. Öğrencinin gelişimine katkıda bulunma & 35 \\
7. Sınıf mevcudunun az olması & 24 \\
8. Kavram yanılgılarını belirleme & 50 \\
9. Öğrencileri değerlendirme sürecine dâhil etme & 38 \\
10. Öğrenci merkezli olması & 37 \\
11. Kolay ve az zaman alması & 41 \\
12. Sinıf mevcudunun az olması & 23 \\
13. Öğrencilerin ilgi ve yeteneklerini belirleme & 35 \\
14. Sorumluk bilinci kazandırması & 33 \\
15. Öğrencinin nesnel değerlendirme becerisinin gelişmesi & 32 \\
\hline 16. Öğrencide Öz eleştiri becerisini geliştirme & 24 \\
17. Öğrencinin arkadaşlarını nesnel olarak değerlendirebilme & 28 \\
becerisini geliştirme & \\
18. Öğretmenin yükünü hafifletmesi & 26 \\
19. Sinav sistemine uygun olması & 38 \\
20. Sinıf düzeyine uygun olması & 33 \\
\hline
\end{tabular}

Tablo 4 incelendiğinde bu çalışmada görüş bildiren öğretmenlerin ölçme ve değerlendirme araçlarının kullanılma nedenleri ve frekansları şöyledir: Öğrencilerin akademik başarısını belirlemesi 57, kullanılan yöntem ve tekniklerin etkililiğini belirlemesi 52, konu bitiminde öğrenme eksiklerinin belirlenebilmesi 53, sınıfın seviyesini belirlemesi 56, öğrencinin hazır bulunuşluk seviyesini belirleyebilmesi 48, öğrencinin gelişimine katkıda bulunma 35, sınıf mevcudunun az olması 24, kavram yanılgilarını belirleme 50, öğrencileri değerlendirme sürecine dâhil etme 38, öğrenci merkezli olması 37, kolay ve az zaman alması 41, sınıf mevcudunun az olması 23, ögrencilerin ilgi ve yeteneklerini belirleme 35, sorumluk bilinci kazandırması 33, 
öğrencinin nesnel değerlendirme becerisinin gelişmesi 32, öğrencide öz eleştiri becerisini geliştirme 24, öğrencinin arkadaşlarını nesnel olarak değerlendirebilme becerisini geliştirme 28, öğretmenin yükünü hafifletmesi 26, sınav sistemine uygun olması 38, sınıf düzeyine uygun olması 33 katılımcı sınıf öğretmeni tarafindan kullanılma nedeni olarak belirtilmektedir.

\section{TARTISSMA ve SONUÇ}

Araştırmanın sorularından birincisi, "sınıf öğretmenlerinin fen bilimleri dersinde kullandıkları yöntem ve teknikler nelerdir?" sorusudur. Bulgular incelendiğinde sırasıyla öğretmenler tarafindan en çok kullanılan yöntem ve tekniklerden, en az kullanılan yöntem ve tekniklere göre; dïz anlatım, gösterip yaptrrma, örnek olay, problem çözme, deney yöntemi, beyin firtunası, kavram haritası, soru cevap, drama, gösteri yöntemi, tahmin gözlem açılama, rol

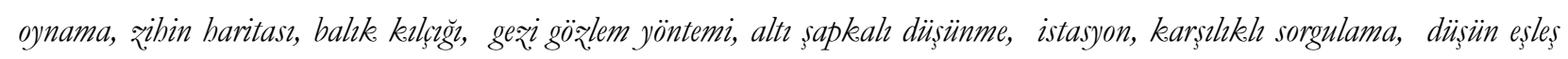
paylass, münazara, kartopu, argümantasyon, v diyagramı, sandviç, jigsaw II, jigsaw I, žt panel şeklinde sıralanmaktadır. Bulgulardan hareketle sınıf ögretmenlerinin fen bilimleri dersinde düz anlatım yöntemine bağlı kalmayıp bunun yanında çoğunlukla öğrenciyi merkeze alan ve aktif kılan yapılandırmacı öğrenme teorisine uygun yöntem ve teknikleri de kullandığı sonucuna ulaşılabilir. Bunun yanında öğrenciyi daha çok aktif kılan ve özellikle kartopu, argümantasyon, jögsaw I-II yöntem ve tekniklerinin daha az kullanıldığı görülmektedir. Ulaşılan bu sonuç, Demirkan ve Saraçoğlu (2016); Şahin ve Güven (2016); Taşkaya ve Sürmeli (2014); Akçay, Akçay ve Kurt (2016); Şimşek, Hırça ve Çoşkun (2012)'un yapmış oldukları araştırma sonuçlarından olan, öğretmenler düz anlatım yönteminin yanında yapılandırmacı yaklaşıma uygun yöntem ve teknikler kullanmaktadır, ifadesi ile benzerlik göstermektedir.

Öğretmenler bu yöntem ve teknikleri belirlerken; konu ve kazanımlara uygun olması, öğrenmenin kalıcılık süresini uzatması, öğrenci merkezli olması, kavram yanılgılarını gidermesi, öğrencilerin hazır bulunuşluk seviyesine uygunluğu, akademik başarıyı arttırması, dersi zevkli ve eğlenceli hale getirmesi, üst düzey düşünme becerilerinin gelişimine katkıda bulunması (eleştirel-analitik- yaratıcı düşünme), birden çok duyu organını kullanmaya imkan tanıması, öğrencilerin etkin katılımını sağlaması, derse yönelik olumlu tutum geliştirilmesi, öğrencilerin ilgisini çekmesi, öğrencileri araştırmaya yönlendirmesi, öğrencilerin dikkatini toplaması, anlamlı öğrenmeyi sağlaması, konuların zamanında yetişmesini sağlaması, farklı zekâ alanlarına hizmet etmesi, farklı öğrenme stillerine hizmet etmesi, öğrencilerin güdülenmesini kolaylaştırması, kolay ve az zaman alması şeklinde belirttikleri faktörleri dikkate aldıklarını belirtmişlerdir. İlgili sonucun alan yazında yapılan araştırmaların (Akçay, Kurt \& Akçay, 2016; Demirkan \& Saraçoğlu, 2016; Özden \& Demir, 2013; Taşkaya \& Sürmeli, 2014) sonuçları ile benzerlik göstermektedir.

Araştırma sorularından ikincisi, "sınıf öğretmenlerinin fen bilimleri dersinde kullandıklanı ölçme ve değerlendirme araçları nelerdir?" sorusudur. Tablo 3 incelendiğinde; çoktan seçmeli testler, yaz̧l yoklamalar, sözllï yoklamalar, boşluk doldurmali testler, doğru yanlıs testleri, eşlesstirmeli testler, performans değerlendirme, kavram haritalari'nın 50'nin üzerinde katılımcı öğretmen tarafından tercih edildiği; portfolyo değerlendirme, poster, öz değerlendirme, derecelendirme ölçĕgi, rubrik, proje, akran değerlendirme, kontrol listesi, yapılandırlmus grid, tanulayıcı dallanmıs ă̆aç ölçme ve değerlendirme araçlarının ise 50'nin altında katılımcı öğretmen tarafindan kullanıldı̆̆ı görülmektedir. Bu sonuca göre, öğretmenlerimizin çoğunlukla geleneksel ölçme araçlarını kullandığı; yapılandırmacı öğrenme teorisinin desteklediği alternatif ölçme ve değerlendirme araç ve tekniklerini daha az kullandığ1 ortaya çıkmaktadır. İlgili sonucun alan yazın yapılan araştırma (Anıl \& Acar, 2008; Dokumacı Sütçü \& Bulut, 2016; Ektem, Keçeci, Pilten, 2016; Gelbal \& Kelecioğlu , 2007; Karamustafaoğlu, Çağlak \& Meşeci, 2012; Özenç, 2013; Özenç \& Çakır, 2015; Şahin, Öztürk \& Teker, 2015; Yazıcı \& Sözbilir, 2014;) sonuçlarından biri olan, öğretmenlerimiz geleneksel ölçme araçlarını; yapılandırmacı öğrenme teorisinin desteklediği alternatif ölçme ve değerlendirme araç ve tekniklerini oranla daha fazla kullanmaktadır, ifadesi ile uyumlu olduğu görülmektedir.

Öğretmenler ölçme değerlendirme araçlarını seçerken, öğrencilerin akademik başarısını belirlemesi, kullanılan yöntem ve tekniklerin etkiliğini belirlemesi, konu bitiminde öğrenme eksiklerini belirlemesi, sınıfın seviyesini belirlemesi, öğrencinin hazır bulunuşluk seviyesini belirleme, öğrencinin gelişimine katkıda bulunması, sınıf mevcudunun az olması, kavram yanılgılarını belirleyebilmesi, öğrencileri değerlendirme 
sürecine dâhil etmesi, kavram yanılg1larını ortaya çıkarması, öğrenci merkezli olması, kolay ve az zaman alması, sınıf mevcudunun az olması, öğrencilerin ilgi ve yeteneklerini belirlemesi, öğrencilere sorumluk bilinci kazandırması, öğrencinin nesnel değerlendirme becerisini geliştirmesi, öğrencilerde öz eleştiri becerisini geliştirmesi, öğrencilerin arkadaşlarını nesnel olarak değerlendirme becerisini geliştirmesi, öğretmenin yükünü hafifletmesi, sınav sistemine uygun olması, sınıf düzeyine uygun olması şeklindeki faktörleri göz önünde bulundurduklarını belirtmişlerdir. Araştırma ilgili sonucunun literatürde yapılan araştırmalar (Anıl \& Acar, 2008; Dokumacı Sütçü \& Bulut, 2016; Ektem, Keçeci \& Pilten, 2016; Özenç \& Çakır, 2015) tarafından da desteklendiği görülmektedir.

Tüm sonuçlar, yapılandırmacı öğrenme teorisinin rehberliğinde değiştirilen programlara karşın, uygulamada aynı teorinin mottoları olan "az bilgi özdür" ve "öğrenme zaman alır" kriterlerinin karşılanamadı̆̆1 göstermektedir. Bu durumun öğretme-öğrenme süreçleriyle ölçme ve değerlendirme uygulamaları arasındaki uyuşmazlığın hala giderilemediğinin işareti olduğu açıktır. Ülkemizde günümüzde de beceri odaklı olmayan ve sonuç odaklı, test tekniklerine dayanan ve kısa süreli sırala sınavları baskın durumdadır (Ektem, Keçeci, Pilten, 2016; Dokumac1 Sütçü \& Bulut, 2016).

\section{1. Öneriler}

1. Öğretmenlere yapılandırmacı öğrenme teorisinin desteklediği ölçme ve değerlendirme araç ve teknikleri, öğretim yöntem ve teknikleri konusunda eğitim verilebilir.

2. Öğretmenlerin kendilerini güncel tutmalarına katkı sağlanabilmesi için lisansüstü eğitime dahil olmaları özendirilebilir.

3. Alternatif ölçme ve değerlendirme araç ve tekniklerinin öğretmenler ve öğrenciler tarafindan daha rahat kullanılabilmesi için öğretmen kılavuz kitapları ve ders kitaplarının içerikleri uygun biçimde düzenlenebilir.

4. Öğretmenlerin sonuç odaklı sınavlara yönelik öğretim süreçlerini tercih etmelerine neden olan tüm sınavların yapısal olarak yapılandırmacı öğrenme teorisine uygun duruma getirilmesine yönelik çalışmalar hızlandirılabilir.

\section{KAYNAKÇA}

Açıkgöz, K., Ü. (2014).Aktif öğrenme. İzmir: Biliş Yayınevi.

Anıl, D., \& Acar, M. (2008). Sınıf öğretmenlerinin ölçme değerlendirme sürecinde karşılaştıkları sorunlara ilişkin görüşleri. Yüzüncü Yıl Üniversitesi Eğitim Fakültesi Dergisi, 5 (2), 44-61.

Aydede, M., \& N., Matyar, F. (2009). Aktif öğrenme yaklaşımının fen bilgisi dersindeki akademik başarı ve kalıcilı̆̆a etkisi. Kastamonu Ë̆itim Dergisi, 17 (1), 137-152.

Aydemir, H. (2012). Sosyal bilgiler öğretmenlerinin öğretim yöntem, teknik ve stratejileri kullanma yeterlikleri. Hikmet Yurdu Dergisi, 5 (9), 81-100.

Aykaç, (2011). Hayat bilgisi dersi öğretim programında kullanılan yöntem ve tekniklerin öğretmen görüşlerine göre değerlendirilmesi (Sinop ili örneği). Kastamonu Ë̆itim Dergisi, 19(1), 113-126.

Akçay, O., N., Akçay, A., \& Kurt, M. (2016). Ortaokul öğretmenlerinin öğretim yöntem ve tekniklerine yönelik görüş ve yeterliklerinin incelenmesi. Ë̆itim ve Ögretim Araştırmalar Dergisi, 5 (1), 333-342.

Akşid, F., \& Şahin, C. (2011). Coğrafya öğretiminde aktif öğrenmenin akademik başarı ve tutum üzerine etkisi. Batı Anadolu Eğitim Bilimleri Dergisi, 2(4), 1-26.

Altunışık, R., Coşkun, R., Bayraktaroğlu, S., \& Yıldırım, E. (2010). Sosyal bilimlerde araştırma yöntemleri spss uygulamalı. Sakarya: Sakarya Yayıncilik.

Baykul, Y., \& Turgut, M., F. (2010). Eğitimde ölçme ve dĕgerlendirme. Ankara: Pegem Yayınevi.

Büyüköztürk, Ş., Çakmak, E. K., Akgün, Ö. E., Karadeniz, Ş., \& Demirel, F., (2016). Bilimsel araştırma yöntemleri. Ankara: Pegem Akademi Yayıncılık.

Çakır, N., Şenler, B., Taşkın, B. (2007). İlköğretim II. kademe öğrencilerinin fen bilgisi dersine yönelik tutumlarının belirlenmesi. Türk Eğitim Bilimleri Dergisi, 5(4), 637-655.

Çepni, S. (2010). Araştırma ve proje çalışmalarna giriş. Trabzon: Yazarın Kendisi.

Çepni, S. (Ed.). (2016). Fen ve teknoloji öğretimi. Ankara: Pegem Akademi.

Demir, S., \& Özden, S. (2013). Sınıf öğretmenlerinin öğretimsel stratejilere yöntemlere ve tekniklere ilişkin görüşleri: Hayat bilgisi dersine yönelik tanılayıcı bir çalışma. Pamukkale Üniversitesi Sosyal Bilimler Enstitüsü Dergisi, Sayı 14, 2013, 59-75. 
Demirkan, Ö., \& Saraçoğlu G. (2016). Anadolu lisesi öğretmenlerinin derslerde kullandıkları öğretim yöntem ve tekniklerine ilişkin görüşleri. The Journal of International Lingual, Social and Educational Sciences, 2(1), 1-11.

Dokumac1-Sütçü, N., \& Bulut, İ. (2016). Ortaokul matematik öğretmenlerinin alternatif ölçme ve değerlendirme tekniklerine ilişkin yeterlik alg1ları ve bu teknikleri kullanma düzeyleri. Dicle Üniversitesi Ziya Gökalp Ë̆itim Fakültesi Dergisi, 29, 289-308.

Efe, R., \& Aslan-Efe, H. (2018). Science student teachers' approaches to studying. International e-Journal of Educational Studies (IEJES), 2 (3), 53-63.

Ektem, S., I., Keçeci, E., S., \& Pilten, G. (2016). Sınıf öğretmenlerinin süreç odaklı ölçme ve değerlendirme yöntemlerine ilişkin görüşleri. Abi Evran Üniversitesi Kurşehir Eğitim Fakültesi Dergisi, 17 (3), 661-680.

Erden, M. (1993). Sosyal bilgiler ögretimi. İstanbul: Alkım Yayınevi.

Gelbal, S. \& Kelecioğlu, H. (2007). Öğretmenlerin ölçme ve değerlendirme yöntemleri hakkındaki yeterlik algilar1 ve karşılaştıklar1 sorunlar. Hacettepe Üniversitesi Eğitim Fakültesi Dergisi, (H. U. Journal of Education) 33, 135-145.

Gözütok, D. (2007). Öğretim ilke ve yöntemleri. Ankara: Ekinoks Yayıncılık.

Güneş, F. (2014). Eğitimde yöntem ve teknik tartışmalanı. International Journal of Language Academy, 2 (4), 23-35.

Hançer, A., H., Şensoy, Ö., \& Yıldırım, H., İ. (2003). İlköğretimde çağdaş fen bilgisi öğretiminin önemi ve nasıl olması gerektiği üzerine bir değerlendirme. Pamukkale Üniversitesi Eğitim Fakültesi Dergisi, 13, 80-88.

Hemlick, J. E., \& Norland, E. V. (1994). I do believe... in Santa? (Cover Story). Adult Learning, 3(5), 22-24.

Karamustafaoğlu,S., Çağlak, A., \& Meşeci, B. (2012). Alternatif ölçme değerlendirme araçlarına ilişkin sınıf öğretmenlerinin öz yeterlilikleri. Amasya Üniversitesi. Eğitim Fakültesi Dergisi, 1(2), 167-179.

Karadüz, A. (2009). Türkçe öğretmenlerinin ölçme ve değerlendirme uygulamalarının yapılandırmacı öğrenme kavramı bağlamında eleștirisi. Uludă̆ Üniversitesi Eğitim Fakültesi Dergisi, 22(1), 189-210.

Kardaş, M. N. \& Öztürk, Y. (2015). Aktif öğrenme tekniklerinin Türkçe öğretiminde başarı tutum ve uygulamalara yönelik öğrenci görüşleriyle ilişkisi: Bir meta- analiz çalışması. International Journal of Languages' Education and Teaching, UDES 2015, 1682-1692. Erişim adresi: http://www.iilet.com/Makaleler/1018201597_Mehmet\%20Nuri\%20KARDA\%C5\%9E\%20\%20\%20 $\% 20 \& \% 20 \% 20 \mathrm{Ye} \% \mathrm{C} 5 \% 9$ Fim $\% 20 \% \mathrm{C} 3 \% 96 \mathrm{ZT} \% \mathrm{C} 3 \% 9 \mathrm{CRK}$.pdf

Kardaş, M., N., \& Uca, N. (2016).Aktif öğrenme yönteminin kullanıldığı çalışmaların öğrenci başarısı, tutumu ve görüşleri açısından incelenmesi: Bir meta-analiz çalışması. Uluslararası Türk Eğitim Bilimleri Dergisi, 4, (7), 118-130.

Kilmen, S., \& Kösterelioğlu, İ. (2017). Öğretmenlerin tamamlayıcı değerlendirme yaklaşımlarına yönelik görüşlerinin cha1d analizi ile incelenmesi. İlkögrretim Online, 16(1), 256-273, 2017.

MEB (2013). İlkögrretim kurumlar fen bilimleri dersi ögretim programı. Ankara: MEB Yayınları.

Lubbers, C. A. \& Gorcyca, D. A. (1997). Using active learning in public relationsinstructions: demographic predictors of faculty use. Public Relations Review, 23(1), 67-80.

Özden, S., \& Demir, S. (2013). Sınıf öğretmenlerinin öğretimsel stratejilere yöntemlere ve tekniklere ilişkin görüşleri: Hayat bilgisi dersine yönelik tanılayıcı bir çalışma. Pamukkale Üniversitesi Sosyal Bilimler Enstitüsü Dergisi, 14, 59-75

Özenç, M. (2013). Sınıf öğretmenlerinin alternatif ölçme ve değerlendirme bilgi düzeylerinin belirlenmesi. Dicle Üniversitesi Ziya Gökalp Eŭitim Fakültesi Dergisi, 21, 157-178.

Özenç, M., \& Çakır, M. (2015). Sınıf öğretmenlerinin alternatif ölçme ve değerlendirme yeterliklerinin belirlenmesi. İlkögretim Online, 14(3), 914-933.

Sakall, M., Hürsen, Ç. \& Özçınar, Z. (2007). The frequent use of teaching strategies/methods among teachers according to the teacher candidates observation. Cypriot Journal of Educational Sciences, 2(1), 1-8.

Savage, T. V. \& Armstrong, D. (1996). Effective teaching in elementary social studies. New Jersey: PrenticeHall.

Slavin, R. E. (1991). Educational psychology. TheorgintoPractice, PrenticeHallInt. Inc.

Slavin, R.E. (2013). Eğitim psikolojisi: Kuram ve uygulama. (Çev: Galip YÜKSEL). Ankara: Nobel Akademik Yayıncilik.

Saygl1, G. (Ed.). (2015). Illkokulda kullanilan strateji, yöntem ve teknikler. Ankara: Pegem Akademi.

Şahin, G., M., Öztürk, B., \& N., Teker, T., G. (2015). Öğretmen adaylarının başarılarının değerlendirilmesinde tercih ettikleri ölçme araçlarının belirlenmesi. Eğitimde ve Psikolojide Ölçme ve Değerlendirme Dergisi, 6 (1), 95-106.

Şahin, D., \& Güven S. (2016). Sınıf öğretmenlerinin fen bilimleri hayat bilgisi ve sosyal bilgiler derslerindeki yöntem ve teknik kullanımına ilişkin görüşleri. Online Fen Eğitimi Dergisi, 1(1): $42-59$.

Şimşek, H., Hırça, N., \& Coşkun, M. (2012). İlköğretim fen ve teknoloji öğretmenlerinin öğretim yöntem ve tekniklerini tercih ve uygulama düzeyleri: Şanlıurfa ili örneği. Mustafa Kemal Üniversitesi Sosyal Bilimler Enstitüsü Dergisi, 9(18), 249-268.

Yıldırım, A., \& Şimşek, H. (2008). Sosyal bilimlerde nitel araştırma yöntemleri. Ankara: Seçkin Yayıncılık. 
Taşkaya, S., M., \& Sürmeli, H. (2014). Sınıf öğretmenlerinin fen ve teknoloji dersinde kullandıkları öğretim yöntemlerin değerlendirilmesi. Gaz̧iantep University Journal of Social Sciences, 13(1):169-181.

Türkben, T. (2015). Aktif öğrenme yöntemiyle oluşturulmuş sınıf ortamınının öğrenciler üzerisindeki etkisi. International Periodical For The Languages, Literature and History of Turkish or Turkic,10 (7), 899-916.

Yazıc1, F., \& Sözbilir, M. (2014). İlköğretim 6-8. sınıf öğretmenlerinin ölçme değerlendirme yöntemlerine ilișkin kullanım sıklıkları ve yeterlik düzeyleri: Erzurum örneklemi. Necatibey Eğitim Fakültesi Elektronik Fen ve Matematik Eğitimi Dergisi, 8 (2), 164-196.

\section{Citation Information}

Apaydın, Z. \& Kandemir, M. A. (2018). Sınıf Öğretmenlerinin Fen Bilimleri Dersinde Kullandıkları Öğretim Yöntem, Teknik ve Değerlendirme Araçlarına İlişkin Görüşleri. Dicle Üniversitesi Ziya Gökalp Eğitim Fakülttesi Dergisi, 33, 70-78. 